\title{
ETIKA KOMUNIKASI ISLAM MASYARAKAT MUSLIM YANG DITERAPKAN DALAM MASYARAKAT MULTI AGAMA DI DESA SUKORENO KECAMATAN UMBULSARI KABUPATEN JEMBER
}

\author{
(Study Kasus Masyarakat Muslim di tengah kehidupan \\ masyarakat Multi-Agama di desa Sukoreno-Umbulsari-Jember)
}

\author{
M. Sofiatul Iman \\ Komunikasi dan Penyiaran Islam Pascasarjana IAIN Jember \\ sofiiman606@gmail.com
}

Diunggah 15 September / Direvisi 20 Oktober / Diterima 01 Desember 2020

\begin{abstract}
Abstrac: Religious harmony needs to be preserved in every aspect of life especially for the multi-religious community of Sukoreno Village. The diversity in that village has led to be the village of Bhineka Tunggal Ika. Muslims are the majoritas in that village. In the researcher's view, The reality of the harmony between Muslims and the Muslim community as the majority in Sukoreno village is there is an ethics of Islamic communication and communication patterns that is built in the community. So that life becomes orderly and balanced among individual.

This research was qualitative through the type of case study research. this research reveals that the communication ethics of the Muslim community in the center of multi-religious community life in Sukoreno village is communication with respect, speaking as it is and not be exaggerating, using gentle speech and not impulsive. The pattern of communication which is built is two-way and linear communication.
\end{abstract}

Keywords: Islamic Communication Ethics, Muslim community, Multi-Religious Society

Korespondensi: M. Sofiatul Iman

IAIN Jember

sofiiman606@gmail.com 


\section{A. PENDAHULUAN}

Islam sebagai agama rahmatan lil alamin tidak menuntut penganutnya mengikuti semua kandungan dan ajarannya yang terdapat di dalam kitab suci secara membabi buta tanpa dipikir secara rasional dan beretika. Pengamalan agama yang tekstulis cenderung akan berdampak pada lahirnya sebuah tindakan bahkan gerakan yang melahirkan realitas ketercekaman hidup dengan berbagai teror dan intimidasi dengan dalih agama. Fenomena demikian banyak terjadi di Indoensia akhir-akhir ini seperti terjadi bom bunuh diri di beberapa wilayah yang meneror kehidupan masyarakat dengan dalih jihad sebagai perintah agama. Gerakan radikal ini merupakan gerakan yang jauh dari fitrah agama itu sendiri turun ke muka bumi. Indonesia merupakan negara muslim terbanyak di dunia berdasarkan data yang dikeluarkan oleh U.S Commision on International religius freedom lebih dari $87 \%$ dari populasi penduduk 258 jt kiwa mengidentifikasi dirinya sebagai muslim. ${ }^{1}$

Data ini menunjukkan populasi muslim Indonesia merupakan populasi yang lumayan mendominasi muslim di berbagai negara dunia, hal ini peneliti menilai bahwa negara Indonesia merupakan negara interpretis Islam dalam pandangan internasional. Keberadaan muslim Indonesia menjadi interpretasi Islam sehingga dengan posisi Indonesia sebagai interpret dari agama Islam menjadi tolak ukur bagaimana perilaku dan tindakan serta gerakan keberagamaan di Indonesia (Islam) akan terbaca oleh dunia. Dalam hal ini jika perilaku keagamaan di Indonesia baik, dunia internasional akan menilainya baik, namun sebaliknya jika perilaku keberagamaan yang ada di Indonesia buruk maka penilaian internasional akan menganggap bahwa Indonesia adalah sarang teroris akibat perilaku masif dan radikal yang dilakukan oknum tertentu di Indonesia dengan dalih agama dengan slogan jihad.

Akhir-akhir ini berbagai tragedi kemanusiaan terjadi di Indonesia misalnya pada tahun 14 Januari 2016 silam bom terjadi di Sarinah Jakarta, 05 Juli 2016 ledakan bom juga terjadi di Mapolresta Solo, 24 Mei ledakan bom juga terjadi di sekitar Kampung Melayu, Surabaya dan Sidoarjo dalam waktu yang bersamaan. Selanjutnya pada yang lebih ironis lagi adalah peristiwa ledakan bom yang terjadi pada 13 Mei 2018 di tiga gereja sekaligus terjadi pada pukul 07.00 wib, di hari yang

\footnotetext{
${ }^{1}$ www.uscrirf.Gov 2017. Lihat dalam www.uscirf.gov/...Indonesia.bahasaChapter\%20Indonesia.translation.pdf.
} 
sama tepatnya pada pukul 19.00 wib ledakan bom kembali terjadi di rusun Wonocolo Sidoarjo, keesokan harinya, 14 Mei 2018 ledakan bom juga terjadi di Mapolresta Surabaya yang dilakukan oleh oknum dalam satu keluaraga ${ }^{2}$ dan melibatkan anak di bawah umur. ${ }^{3}$

Rangkaian peritiwa teror bom yang terjadi di atas yang menjadi sasaran antara lain adalah hotel, temapat ibdah umat kristiani (gereja) dan markas kepolisian. Hal ini mereka lakukan bukan tanpa alasan, mereka beranggapan bahawa hotel adalah tempat penginapan yang sering dijadikan tempat maksiat sehinngga wajib ditumpas menurut mereka, begitu pula dengan temapat ibadah umat kritiasni yang notabene berseberangan keyakinan dengan Islam, begitu pula dengan markas kepolisian yang merupakan aparat negara yang selalu membela dan menegakkan hukum negara berdasarkan undang-undang dan pancasila, hal ini ditafsiri oleh ektrimis Islam sebagai hukum di luar hukum Allah yang harus diperangi karena mereka para ektrimis menganggapnya sebagai thagut.

Apapun alasan mereka kaum radikal dalam melancarkan aksi teror di Indonesia merupakan tindakan yang tidak memandang aspke kemanusiaan atau dapat dikatakan tindakan mereka merupakan tindakan yang tidak berperi kemanusiaan walaupun mereka berdalih jihad atas nama agama. Hal ini menunjukkan bahwa mereka memahami agama secara tekstulis dan tidak mengkaji secara aspek konteks sosio-kultural yang ada di Indonesia sehingga mereka dalam berperilaku keagamaan cenderung melahirkan suasana mencekam dan bersifat teror dalam kehidupan, sehingga muncul istilah Islamophobia akibat dari kegagalan mereka mengkomunikasikan pesan-pesan agama yang terkodifikasi dalam bentuk teks.

Kenyataan demikian ini memposisikan seorang muslim yang membawa nama islam sebagai agama penuh rahmat dan cinta damai semakin jauh dari fitrah agamanya sebab mereka yang memamahmi agama secara ekstrim akan banyak musuh dan menganggap kelompok yang diluar kelompoknya serta yang berbeda pandangan dianggap syirik, kufarat dan secamacamnya dan wajib diperangi, jika kondisi demikian dibiarkan maka akan mengancam keutuhan negara kesatuan republik Indonesia. Kelompok seperti ini jangankan dengan kelompok yang beda

2 Kompas .com

3 Tribun medan.com 
keyakinan (non muslim), dengan sesama muslim saja yang berbeda aliran sudah menjadi lawan, apalagi dengan non muslim yang sudah jelas berbeda aqidah.

Namun berbeda dengan masyarakat desa Sukoreno kecamatan Umbulsari Kebupaten Jember. Desa Sukoreno berdasarkan data BPS Jember tercatat jumlah penduduk tahun 2017 berdasarkan jenis kelamin terdiri dari 4.405 laki-laki dan 4.504 perempuan dangan tola keseluruhan jumlah penduduk adalah 8.909 jiwa, 4 sedangkan dari aspek keagamaan masyarakat desa Sukoreno didominasi oleh masyarakat muslim, data BPS Jember tahun 2017 tercatat 7.152 pemeluk agama Islam, 35 Protestan, 110 Katolik, 124 Hindu, dan 15 penganut agama Budha. ${ }^{5}$

Desa Sukoreno merupakann desa yang dihuni oleh berbagai agama. Masyarakat desa sukoreno hidup berdampingan antar sesama penganut agama, sebgaimana ungkapan yang dinyatakan oleh salah seorang tokoh masyarakat desa Sukoreno bahwa di dalam kehidupan bermasyarakat desa Sukoreno tidak pernah ada gejolak konflik, meski terdapat perbedaan yang mencolok namun masyarakat muslim desa Sukoreno sebagai kaum mayoritas tetap mengayomi dan bila ada halhal yang tidak cocok maka sikap yang ditempuh adalah ad'aful iman, atau diam saja namun hati menolak terhadap perilaku yang dianggap menyimpang dari agama Islam.

Di dalam perayaan ogoh-ogoh sebagai ritual panyambutan hari raya nyepi bagi umat Hindu, masyarakat muslim juga ikut membantu mempersiapkan acara yakni masyarakat muslim terlibat dalam kepanitiaan, ${ }^{6}$ hak serupa juga dikatakan oleh ibu Nur Hayati bahwa di rumah tempat tinggalnya (gang 5 desa Sukoreno) mayoritas muslim namun mereka tetap dapat hidup berdampingan dengan orang non muslim kadangkala orang di wilayah gang 5 bertamu kepada orang non muslim yang bertempat tinggal di gang 1 hanya sebatas ngobrol seputar pertanian dan semacamnya. ${ }^{7}$

Relasi harmonis antara masyarakat muslim desa Sukoreno dengan non muslim ini merupakan relasi yang dibangun bedasarkan komunikasi yang efektif. Komunikasi sebagai ruh kehidupan sosial dengan pertukaran makna dan simbol

\footnotetext{
4 Badan Pusat Statistik Kabupaten Jember, Kecamatan Umbulsari dengan angka 2018 (Jember : BPS Jember, 2018), 9-11

5 Ibid, 40. Data ini juga disajikan dalam BPS Kabupaten Jember, Kecamatan Umbulsari Dalam Anga 2018 (Jember : BPS Jember, 2019),22

${ }^{6}$ Samsul Huda, wawancara Sukoreno (28 Januari 2020)

${ }^{7}$ Nurhayati, Sukoreno, wawancara (21 Januari 2020)
} 
dalam transaksi antar individu memberikan ruang yang dapat melahirkan sebuah lingkungan hidup yang harmoni. Dalam konteks komunikasi, hibungan antar individu dapat berjalan dengan baik secara simultan karena etika di dalam komunikasi tetap dipraktekkan dalam pola komunikasi interelasi di desa Sukoreno.

Etika komunikasi merupakan ilmu atau kerangka kontruksi berfikir untuk menilai baik dan buruk. Kebaikan dan keburukan dalam konteks keislaman bersumber dari sumber hukum Islam yakni al-qur'an dan hadits. Di dalam konteks penelitian ini al-qur'an dan hadits merupakan sebuah perangkat ukur yang final dalam setiap kegiatan atau tindakan komunikmasi Islam sehingga nilai-nilai etis di dalam komunikasi bagi masyarakat muslim menyandarkan tindakannya pada nilainilai etis yang terkandung di dalam al-qur'an dan hadits. Dengan menggunakan teori interpersonal Joseph De Vito dan interaksionisme simbolik Habermead peneliti berupaya untuk mengkaji etika komunikasi Islam pada realaitas kehidupan muslim di tengah kehidupan masyarakat multi agama di desa Sukoreno

Oleh kerena itu, penelitian ini berfokus pada etika monukasi masyarakat muslim di tengah kehidupan masyarakat multi agama di desa Sukoreno dan juga pola komunikasi masyarakat Sukoreno dalam menjaga kerukunan umat beragama.

\section{B. PEMBAHASAN}

\section{Sejarah Desa Sukoreno}

Desa Sukoreno awalnya bernama Gumuk Lengar yang diambil dari sebuah bukit padas yang sering didatangi orang untuk menggali padas ketika ditemukan sebuah arca yang berada di bawah pohon Suko atau kembang suko yang bunganya 4 macam warna, maka setelah ditemukan arca itu nama desa diganti dengan nama desa Sukoreno yang mempunyai arti bermacam-macam kesenangan yang dipadukan dengan karakter masyarakat dan keragaman agama yang dianut masyarakat.

Menurut data dokumen desa kepala desa pertama di desa Sukoreno bernama Suwadi sejak tahun 1933 dan pada tahun 1941 Desa Sukoreno dipimpin oleh Kepala Desa bernama Kasbiran selama 9 tahun dan pada tahun tahun 1949, terjadi pergantian Kepala Desa dengan cara pilihan yang akhirnya Kepala Desa dipimpin oleh seorang yang bernama Supardi. Supardi memimpin desa Sukoreno selama 8 tahun. Kemudian pada tahun 1957 kembali diadakan pemilihan kepala desa dengan hasil pemenangan yang diraih oleh seorang bernama Jumali, hingga 12 tahun 

tepatnya pada tahun 1969 masa kerja Kepala desa Jumali habis jabatannya, dan kondisi desa masih belum tertata serta belum kondusif

Ketika keadaan Desa belum kondusif, maka Bupati jember mengambil Kebijakan menempatkan atau menunjuk anggota ABRI yang bernama Ibnu Sunardi untuk ditugaskan di Desa Sukoreno sebagai Kepala Desa Sukoreno atau lebih dikenal dengan sebutan kepala desa Karteker. Saat kepemimpinan Ibnu Sunardi pemerintahan desa mulai ditata atau dibagi menjadi 5 ( lima ) dusun yaitu Dusun Krajan Kidul, Dusun Krajan Lor, dusun Kandangrejo, Dusun temurejo, Dusun Blokmundu. Tahun 1980 terjadi pilihan Kepala Desa yang akhirnya dimenangkan oleh seorang Calon bernama Ali Mustaqim Junaedi, BA. Kemudian pada tahun 1990 kembali diadakan pilihan Kepala Desa yang akhirnya dimenangkan oleh seorang yang bernama Drs. Supingin dan pada tahun 1998 pemilihan Kepala Desa lagi dimenangkan oleh seorang nama Sudariyanto, SH.Mhum. ketika tahun 2005 terjadi pemecahan Desa yang akhirnya Desa Sukoreno dipecah menjadi 2 Desa yaitu : Desa Sukoreno dan desa Mundurejo.

Maka mulai Tahun 2005 Sukoreno terdiri dari 3 ( tiga ) yaitu : Dusun Kandangrejo, Dusun Krajan Kidul dan Dusun Krajan Lor. Adapun nama-nama Kepala Dusun masing masing adalah sebagai berikut : Waris, Saeroji, dan Supriyono. Setelah masa Kepala Desa Sudariyanto habis masa jabatannya yaitu tahun 2006 , maka awal tahun 2007 tepatnya di bulan februari ada Pemilihan Kepala Desa dan dimenangkan oleh saudara Achmad Choiri dan sampai saat ini (tahun 2019-2020) beliau masih menjabat sebagai Kepala Desa Sukoreno.

Desa Sukoreno mempunyai luas : 836,862 Ha, terdiri dari batas desa:
a. Sebelah Utara
: Desa Mundurejo
b. Sebelah Timur
: Desa Gunungsari
c. Sebelah Selatan
: Desa Wonorejo
d. Sebelah Barat: Desa Wriginagung

Yang secara administratif Desa Sukoreno terbagi dalam 3 ( tiga ) dusun,yaitu :
a. Dusun Krajan Kidul
b. Dusun Krajan Lor
c. Dusun Kandangrejo
d. Jumlah RW : 21
e. Jumlah RT : 64 
f. Jumlah Posyandu $\quad: 10$

g. Jumlah Dasa Wisma $\quad: 1$

h. Jumlah penduduk : 8.909 jiwa, yang terdiri dari :

Laki laki

: 4.455 jiwa

Perempuan

: 4.454 jiwa

Jumlah KK

$: 2.611 \mathrm{KK}^{8}$

Berdasarkan data Administrasi Pemerintahan Desa tahun 2010, jumlah penduduk Desa Sukoreno adalah 9711 jiwa, dengan rincian 4802. laki-laki dan 4909 perempuan. Jumlah penduduk demikian ini tergabung dalam $2847 \mathrm{KK}$.

Agar dapat mendeskripsikan dengan lebih lengkap tentang informasi keadaan kependudukan di Desa Sukoreno. maka perlu diidentifikasi jumlah penduduk dengan menitikberatkan pada klasifikasi usia. Untuk memperoleh informasi ini maka perlul dibuat tabel sebagai berikut:

Tabel 4

Jumlah Penduduk Berdasarkan Usia

\begin{tabular}{|c|l|c|c|}
\hline No & \multicolumn{1}{|c|}{ Usia } & Jumlah & Prosentase \\
\hline 1 & $0-4$ & 498 orang & $6,14 \%$ \\
\hline 2 & $5-9$ & 762 orang & $9,39 \%$ \\
\hline 3 & $10-14$ & 581 orang & $7,17 \%$ \\
\hline 4 & $15-19$ & 686 orang & $8,46 \%$ \\
\hline 5 & $20-24$ & 664 orang & $8,19 \%$ \\
\hline 6 & $25-29$ & 728 orang & $8,98 \%$ \\
\hline 7 & $30-34$ & 681 orang & $8,39 \%$ \\
\hline 8 & $35-39$ & 633 orang & $7,81 \%$ \\
\hline 9 & $40-44$ & 599 orang & $7,39 \%$ \\
\hline 10 & $45-49$ & 601 orang & $7,42 \%$ \\
\hline 11 & $50-54$ & 240 orang & $2,96 \%$ \\
\hline 12 & $55-58$ & 244 orang & $3,01 \%$ \\
\hline 13 & $>59$ & 1192 orang & $14,69 \%$ \\
\hline \multicolumn{2}{|c|}{ Jumlah Total } & 8109 orang & $\mathbf{1 0 0} \%$ \\
\hline
\end{tabular}

8 Berdasarkan data dokumntasi desa dan sensus penduduk tingkat desa tahun 2018. 
Dari data di atas nampak bahwa penduduk usia produktif pada usia 20-49 tahun Desa Sukoreno sekitar 3.906 atau hampir 48,18 \%. Hal ini merupakan modal berharga bagi pengadaan tenaga produktif dan SDM.

Tingkat kemiskinan di Desa Sukoreno termasuk tinggi. Dari jumlah 2847 KK di atas, sejumlah 10 \% KK tercatat sebagai Pra Sejahtera, 45 \% KK tercatat Keluarga Sejahtera I, 30 \% KK tercatat Keluarga Sejahtera II, 10 \% KK tercatat Keluarga Sejahtera III dan 5 \% KK sebagai sejahtera III plus. Jika KK golongan Pra-sejahtera dan KK golongan I digolongkan sebagai KK golongan miskin, maka lebih 55 \% KK Desa Sukoreno adalah keluarga miskin

\section{Sarana peribadatan}

a. Jumlah Musholla Dusun Krajan Kidul : 23 buah

b. Jumlah Musholla Dusun Krajan Lor : : 12 buah

c. Jumlah Musholla Dusun Kandangrejo : : 19 buah

d. Jumlah Masjid Dusun Krajan Kidul : 2 buah

e. Jumlah Masjid Dusun Krajan Lor $\quad: 2$ buah

f. Jumlah Masjid Dusun Kandangrejo : 3 buah

g. Jumlah Pura Dusun Kandangrejo : 1 buah

h. Jumlah Pura Dusun Krajan Kidul : 1 buah

i. Jumlah Gereja Katholik Dusun Krajan Kidul : : 1 buah

Etika Komunikasi Islam Masyarakat Muslim yang diterapkan dalam masyarakat Multi Agama di desa Sukoreno kecamatan Umbulsari Kabupaten Jember

\section{a. Saling menghargai}

Masyarakat desa Sukoreno merupakan mayoritas masyarakat yang bermata pencaharian bertani. Pekerjaan mereka rata-rata di sawah, setiap hari bekerja bersama-sama baik muslim ataupun non muslim. Pekerjaan yang sama tentunya akan membawa hubungan interaksi sosial begitu dekat antar individu. Pada saat bulan puasa mereka tetap bekerja bersama di dalam satu sawah yang sedang digarap, masyarakt muslim dengan nn muslim tetap saling enghargai, pada bulan Ramadhan meski mereka bersama-sama dalam bekerja di tempat yang sama, namun mereka tetap saling menghargai, semisal orang non muslim pada bulan ramadhan makan di sawah karena dikirim oleh pemilik sawah. 
Mereka orang non muslim makan di siang hari di sawah tempat bekerja yang mana di tampat yang sama juga terdapat orang muslim yang sedang menjalankan ibadah puasa. Yang muslim mempersilahkan mereka makan dan tidak mnganggu, begitu pula yang non muslim tidak menawari makan kepada orang mulsim karena mereka menghargai kalau muslim di bulan ramadhan menjalankan ibadah puasa.

Selain itu, di dalam kehidupan mayarakat muslim Sukoreno saling menghargai anat sesama umat beragama dengan menhadiri undangan hajatan milki orang non muslim. Seorang yang beragama Islam di desa Sukoreno turut hadir bilamana ada undangan dari non muslim yang punya hajat atau kenduri. Hal hal ini dilakukan untuk menjaga keseimbangan hubungan antar individu dalam lingkunagn masyarakat secara sosial,

Dari realitas ini dapat dipahami komunikasi etika komunikasi Islam masyarakat muslim di tengah kehidupan masyarakat multi agama adalah dengan saling menghargai dalam aspek sosial artinya mereka mau hidup berdampingan dan saling menghargai satu dengan yang lainnya sebatas hubungan hablumminnas, bukan berkaitan dengan ibadah.

Perlaku keagamaan berupa hadirnya masyarakat muslim pada hajatan non muslim semata-mata karena menghargai secara kemanusiaan. Perliku masyarakat antar individu saling membangun sebuah mean (pesan) yang telah disepakati bersama dan dipahami bersama oleh masyarakat sehingga perasaan tidak enak, kurang nyaman ketika tidak datang manakala mendapat undangan merupakan pranata sosial yang terbangun dari adanya makna dari sebuah hungan sosial melalui komunikasi.

Komunikasi non verbal berupa gerak tubuh (tidak menganggu) masyarakat non muslim yang sedang makan di sawah pada siang hari ini menunjukkan adanya saling menghargai antar sesama umat beragama di desa Sukoreno. Perikalu lain yang ditunjukkan oleh masyarakat muslim Sukoreno adalah hadirnya masyarakat muslim pada acara hajatan tertentu yang dilakukan oleh non muslim. Masyarakat non muslim di desa Sukoreno kalau mempunyai hajatan tertentu -kalau dalam versi islam selamatenan, kenduri dan semacamnya- turut mengundang orang islam yang bertetangga dengan yang punya hajat tersebut. 


\section{b. Berbicara apa adanya dan tidak berlebihan}

Dalam perspektif komunikasi berbicara tentu ada yang dibicarakan, pembicara dan orang yang diajak bicara serta adanya bahan (materi) pembicraan yang disebut dengan pesan atau isi pesan. Pesan-pesan yang disampaikan masyarakat muslim Sukoreno di dalam berinteraksi dengan masyarakat yang berbeda keyakinan adalah dengan pesan yang sederhana, apa adanaya dan tidak berlebihan.

Pembicraan (pesan) yang sederhana dan apa adanya di dalam berkomunikasi adalah kesesuaian antara ucapan dengan realitas atau fakta yang riil terjadi. Masyarakat muslim Sukoreno tidak melebih-lebihkan pembicaraan dalam berkomunikasi dengan masyarakat non muslim. Perkataan yang tidak sesuai dengan kenyataan merupakan pembicaraan yang tidak berbobot atau hanya omong kosong belaka, oleh karenanya masyarakat muslim Sukoreno tidak menggunakan bahasa yang berlebihan dalam berkomunikasi dengan masyarakat non muslim.

\section{c. Pembicaraan tidak menyinggung keyakinan}

Keyakinan dalam konteks kajian teologi Islam biasanya disandingkan dengan aqidah dan memiliki arti ikatan, aqidah merupakan pengikat keimanan seseorang yang tertanam di dalam hati sanubari dan bila keyakinan seseorang merasa dilecehkan cenderung memicu kekuatan yang mendorong pemiliknya untuk membela mati-matian keyakinan yang merasa dilecehkan.

Oleh karenanya, secara etis masyarakat desa Sukoreno dalam berkomunikasi dengan masyarakat non muslim tidak pernah menyinggungpersoalan keyakinan karena menghindari hal-hal yang berpotensi terjadinya konflik yang dipicu atas nama agama. Kerukunan dan kebersamaan yang telah terbangaun sejak lama tetap harus dipertahan dan diletarikan demi kelangsungan keseimbangan hidup.

Keyakinan yang telah mendarah daging pada setiap individu akan merasa apa yang mereka yakini merupakan kebenaran mutlak yang tidak bisa dirubah walau dengan cara apapun. Sehingga hal yang sedemikian tidak seharusnya dijadikan sebagai bahan pembicaraan baik itu dalam kondisi bercana terlebih serius, masyarakat desa Sukoreno saling memahami terkait keyakinan antar pemeluk agama memang sudah berbeda dan hal itu merupakan hak mereka 

masing-masing, sehingga pembicaraan yang mengarah pada keyakinan tidak perlu dibicarakan lagi, bagi masyarakat desa Sukoreno perkara keyakinan merupakan urusan final yang tidak perlu diotak-atik .

\section{d. Tutur kata halus, sopan dan lemah lembut}

Tutur kata yang halus, sopan, lemah lembut serta tidak memaksakan kehendak diri kepada komunikan merupaka perintah agama yang telah diabadikan di dalam al-qur'an. Bisa dilihat pada QS Thaha ayat 20. Penafsiran ibn katsir terhadap ayat ini qaulan layyinan yang memilki arti bahwa perkataan yang meresap ke dalam jiwa komunikan.

Masyarakat muslim Sukoreno berkomunikasi dengan masyarakat yang berbeda keyakinan dengan menggunkan tutur kata yang dapat meresap ke jiwa. Maksudnya halusnya kata-kata yang digunanakan (sopan) akan membuat masyarakat yang berbeda keyakinan akan kagum terhadap komunikasi yang digunakan. Pesan yang lembut, halus dan santun dalam pembicaraan akan membuat komunikan menjadi senang sehingga hati mereka senang dengan komunikasi yang halus dan lembut enak didengar.

\section{Pola Komunikasi Masyarakat Muslim dalam menjaga kerukunan masyarakat}

\section{Multi Agama di desa Sukoreno kecamatan Umbulsari kabupaten Jember}

\section{a. Pola komunikasi dua arah}

Transaksi simbol yang dilakukan oleh dua orang atau lebih yang kemudian dua orang tersebut akan saling mengerti dengan pesan-pesan yang disamapikan melalaui simbol tersebut adalah merupakan dari pengertian pola komunikasi. Untuk menjaga kerukunan antara umat neragama masyarakat muslim Sukoreno menggunkan pola komunikasi dengan pola dua arah. Yakni komunikasi dengan saling menghargai satu dengan lainnya sebagai individu yang merupakan bagian dari realitas masyarakat. Selain saling menghargai, masyarakat muslim Sukoreno di dalam menjaga kerukunan antar umat beragama menggunakan pola komunikasi saling mengayomi antar satu dengan masyarakat lainnya.

Sebagai media interaksi antar individu di masyarakat Sukoreno, komunikasi menjadi penentu dalam menciptakan realitas realsi sosial masyarakat, sehingga komuikasi menjadi bagian terpenting dalam menciptakan realitas kerukunan dalam hubungan masyarakat di desa Sukoreno sebagai wujud 

dari terealisasinya Bhineka tunggal ika sebagai falsafah Negara Kesatuan Republik Indonesia.

Pola komunikasi yang dibangun masyarakat muslim desa Sukoreno dengan berhati-hati dalam berbicara agar tidak menyinggung hati dan perasaan orang yang lain keyakinan. Sehingga kerukunan dapat tercipta. Berdasarkan penuturan H. Syuaib bahwa untuk menjaga harmoni hubungan jangan sampai bersikap sombong yang kemudian nanti akan menimbulkan respon negatif dari tetangga sebelahnya. Begitu halnya ungkapan Supat dalam menjaga kerukunan umat beragama di desa Sukoreno pola komunikasi yang dibangun adalah komunikasi yang saling menerima dan saling menghargai perbedaan yang ada. Khususnya ketika sedang bertamu ke rumah tetangga yang berbeda agama bicara kita harus sopan, jangan menggunakan bahasa yang kasar apalagi ada kalimat bentakan. Selain itu Supat juga menyatakan untuk menjaga kerukunan umat beragama di desa Sukoreno adalah dengan berkomunikasi yang tidak menimbulkan saling curiga.

\section{b. Pola komunikasi linier}

Aktivitas komunikasi masyarakat muslim Sukoreno dengan masyarakat non muslim berlangsung secara terus menerus, dari satu titik ke titik lainnya, dari komunikator kepada komunikan. Dan pada sat proses komunikasi terjadi antara kedua individu merupakan termainal dalam transmisi pesan melalui simbol komunikasi yang dipergunakan.

Simbol beruapa bahasa yang sama-sama dimengerti masyarakat dan dipergunakan dalam setiap aktivitas hidup adalah media komunikasi penyampaian pesan bagi masyarakat Sukoreno. Hal ini dapat dilihat dari bagaimana proses komunikasi yang terjadi antar H.Syuaib degan masyarakat non muslim saat bekerja, Said saat rapat dengan non muslim, Legimin saat berinteraksi dengan masyarkat non muslim. Semua menunjukkan bahasa lisan sebagai media komunikasi.

\section{Metodologi}

Penelitian ini menggunakan metode penelitian kualitatif agar peneliti dapat lebih leluasa dalam menggali data-data yang dibutuhkan yang sesuai dengan tema atau fokus penelitian selama di lokasi penelitian. Penelitian kualitatif dipilih karena beberapa alasan sebagai berikut, pertama di dalam penelitian kualitatif terdapat 
partisipasi penelitian atau intensitas peneliti dalam waktu yang lama dan dalam setting lapangan dalam hal ini posisi peneliti adalah sebagai intrumen penelitian. Kedua, penelitian kualitatif memandang realitas sebagai suatu kesatuan (holistik) yang tidak bisa dipilah-pilah. Ketiga, penlitian kulitatif dalam operasionalnya menitikberakan pada keladaman data (depth) dari pada keluasan data (breadth). ${ }^{9}$ Dengan demikiian penelitian lebih leluasa dalam menggali data-data yang dibutuhkan sesuai dengan topik bahasan dalam penelitian.

Jenis penelitian ini adalah study kasus. Peneliti menggunakan jenis penelitian studi kasus karena objek penelitian di desa Sukoreno merupakan wilayah yang realitas masyarakatnya adalah heterogen. Heterogenitas masyarakat desa Sukoreno menjadi ketertarikan peneliti untuk dikaji lebih mendalam gejala-gejala sosial yang dapat diindera melalui jenis penelitian studi kasus, sebab studi kasus menurut Mudjia Rahardjo tidak difokuskqan untuk mengambil kesimpulan secara umum atau memperoleh generalisasi sehungga tidak membutuhkan sample dan populasi. ${ }^{10}$

Peneliti langsung terjun di lokasi berbaut dengan masyarakat Sukoreno dalam rangka observasi dan mencatat segala apa yang dapat peneliti amati di lokasi penelitian. Peneliti jua mengobservasi relasi komunikasi yang dibangun ketika ada momentum pertemuan antar umat beragama yang diadakan oleh FKUB (forum kerukunan umat beragama) yang bertempat di kantor desa Sukoreno. Kemudian peneliti juga mendatangi beberapa tokoh agama Islam untuk wawancara tentunya tokoh agama ini adalah orang yang betul-betul masyarakat yang tinggal di desa Sukoreno dan sudah banyak pengalaman terkait dengan relasi keagamaan dan hubungan masyarakat muslim di desa Sukoreno dengan masyarakat non muslim.

Kehadiran peneliti di desa Sukoreno merupakan hal yang pokok di dalam penelitian ini karena peneliti merupakan instrumen penelitian sehingga setiap malam peneliti bertamu kepada informan yang telah memenuhi kriteria dan dianggap dapat menjawab persoalan yang ada pada fokus penelitian. Selama di dalam perjalanan keliling desa Sukoreno peneliti juga nengamati aktivitas kegamaan beruapa muslimatan, yasinan terutama di gang 3 Sukoreno yang setiap malam terdapat aktivitas keagamaan. Aktivitas keagamaan Islam di tengah kehidupan

\footnotetext{
9 Rahmat Kriyantono, Teknik Riset Komunikasi (Jakarta : Kencana, 2008), 57-58

10 Mudjia Raharjo, Studi kasus dalam penelitian kualitatif(Bandung : Remaja Rosda Karya, 2017),9.
} 

masyarakat multi agama ini di dalamnya interaksinya terdapat komunikasi yang sedang peneliti amati.

\section{Temuan dan Diskusi}

Setelah peneliti melakukan observasi dan wawancara serta dokumentasi di desa Sukoreno, maka peneliti menemukan data-data penelitian yang berkaitan dengan etika komunkasi Islam masyarakat muslim yang diterapkan di dalam masyarakat multi agama. Temuan penelitian ini dilakukan dengan analisis melalui reduksi data, yaitu mengambil data-data yang sesuai dengan tema penelitian, serta data yang telah sesuai dengan tema kemudian diorganising untuk kemudian di verifikasi sehingga temuan di dalam tesis ini akan dideskripsikan sebagai berikut :

1. Etika Komunikasi Islam Masyarakat Muslim yang diterapkan dalam masyarakat Multi Agama di desa Sukoreno kecamatan Umbulsari Kabupaten Jember

Masyarakat Muslim desa Sokoreno di dalam menjalin hubungan dengan masyarakat yang berbeda agama termasuk masyarakat yang dapat menerapkan etika komunikasi Islam.

Etika komunikasi Islam yang dijadikan sebagai landasan untuk mengukur baik dan buruknya komunikasi serta didasarkan kepada dalil-dalil al-Qur'an dan hadits dapat kita lihat bagaimana cara masyarakat Muslim Sukoreno berkomunikasi dengan masyarakat non muslim. Pernyataan yang dikatakan oleh H. Syuaib bahwa masyarakat Sukoreno mayoritas $90 \%$ muslim dan yang melaksanakan ibadah tidak lebih dari 50\%, dan bagi yang taat beribadah tidak mengusik atau menasehati mereka karena agar tidak terjadi gesekan. Ini menunjukkan bahwa masyarakat desa Sukorena menghargai hak individu sesama muslimnya dalam konteks keharmonisan hubungan.

Begitu pula interaksi masyarakat muslim Sukoreno dengan masyarakat non muslim, di mana bagi masyarakat muslim Sukoreno kebersamaan atau kerukunan itu adalah hal yang paling utama di dalam interaksi masyarakat bertetangga, masyarakat muslim Sukoreno berkenan untuk menghadiri acara hajatan non muslim. Masyarakat non muslim di desa Sukoreno yang mengundang masyarakat muslim pada acara hajatan di rumahnya ketika 

menghaturkan ke rumahnya terlebih dulu memberi tahu bahwa hidangan ikan yang akan disuguhkan di acara hajatannya disembelih oleh kiai dari muslim. ${ }^{11}$

Realitas ini menunjukkan bahwa etika komunikasi Islam yang diterapkan oleh masyarakat muslim Sukoreno berlangsung efektif. Masyarakat desa Sukoreno jika ke sawah bekerja dan bersama dengan masyarakat non muslim saling menghargai satu sama lain. sebagaimana ketika bulan puasa mereka secara interpersonal saling berkomunikasi dengan bahasa verbal berupa tidak pernah mengajak untuk merokok, makan bersama di siang hari, walaupun non muslim makan di areal sawah yang terdapat masyarakat muslim. Masyarakat muslim tidak mengganggu atau berkomentar terkait tindakan yang dilakukan oleh masyarakat non muslim. Secara non verbal juga dapat dibayangkan pada kebiasaan masyarakat Sukoreno jika makan dan ada orang lain di sawah biasanya menawari dan mengajak makan, namun pada saat masyarakat muslim puasa mereka yang non muslim makan di sawah tidak menawarinya, artinya dalam konteks ini tidak ada simbol verbal berupa bahasa yang terucap dari dari interpersonal mereka, hanya saja bahasa tubuh berupa diam dan langsung makan tanpa menawari muslim untuk makan.

Komunikasi yang dibangun masyarakat muslim dengan non muslim di desa Sukoreno secara interpersonal dapat dilihat di mana komunikasi di atas merupakan komunikasi yang saling mengerti dan memahami pertukaran simbolsimbol verbal berupa bahasa antar komunikator dengan komunikan. Komunikasi diadik ini berisi tentang komunikasi muslim yang tetap mengedepankan dan berlandaskan perintah agama (etika komunikasi Islam). Komunikasi tersebut memperlihatkan seorang non muslim yang bekerja memetik jeruk milik masyarakat muslim.

Ketika sedang berada pada jam kerja, seorang non muslim meminta rokok kepada H. Syuaib pemilik sawah, namun H. Syuiab menolak dengan bahasa datar dan terus ditanggapi oleh non muslim dengan bahasa datar pula. H. Syuaib tetap tidak mau untuk memberikan rokok, makan dan minum, dengan alasan seorang yang sedang menjalankan ibadah puasa tidak boleh memberikan makanan, minuman dan rokok kepada orang yang tidak berpuasa. Namun di sisi lain, $\mathrm{H}$.

11 Data ini berdasarkan hasil wawancara dengan H.Syuaib pada 17 Juni 2020, dan juga pak Musholli, 20 juni 2020,pak widodo 24 Juli, pak mesdi 15 April 2020, Nur Hayati, 8 Juni 2020 
Syuaib tidak melarang jika seorang non muslim yang bekerja di sawahnya untuk makan, minum dan merokok jika mereka membawa sendiri tanpa meminta kepada dirinya.

Etika sebagai ilmu untuk menilai baik dan buruk yang dianut oleh masyarakat ${ }^{12}$ Sokoreno dalam mengatur perilaku mereka dengan tidak saling menganggu satu dengan lainnya. saling memberikan kesempatan serta memberikan kebebasan untuk mengekspresikan perilaku keagamaan yang dianut masing-masing masyarakat. Interaksi masyarakat muslim Sukoreno sudah terjalin sejak lama sehingga kebiasaan-kebiasaan yang sudah mendarah daging tidak bisa dirubah hanya dengan alasan sebuah keyakinan.

Sebuah toleransi antar umat beragama yang terjalin dengan baik, interaksi antar masyarakat dapat terus berlanjut karena mereka memiliki makna dalam interaksinya yaitu sebuah kerukunan yang terjalin di mana kerukunan antar umat bagi masyarakat muslim Sukoreno merupakan sesuatu yang sangat berarti demi kelangsungan hidupnya. Mereka memahami satu dengan lainnya, hubungan mereka didasarkan pada aspek relasi sosial atau hubungan antar sesama manusia bukan mau mencampur keyakinan.

Masyarakat muslim Sukoreno berinteraksi dengan masyarakat non muslim dari aspek sosial bukan dari keyakinan apa lagi mencampur adukkan keyakian.

Komunikasi yang dibangun dengan masyarakat non muslim beretika, dapat dinilai baik dari aspek sosialnya kerena dengan pernyataan berupa "Mereka yang kristen silahkan beribadah sesuai dengan agamanya, begitu pula yang Katholik, Islam beribadah sesuai dengan aturan agamanya masing-masing" menunjukkan etika komunikasi yang diterapkan oleh masyarakat muslim di dalam kehidupan masyarakat multi agama. Legimin juga menggaris bawahi bahasanya bahwa sikap yang dilakukannya merupakan sikap interaksi sebatas aspek kemanusiaan saja tidak ikut serta meyakini apa yamg diyakini non muslim.

Keakraban yang tampak pada masyarakat muslim dengan masyarakat non muslim terjadi karenanya adanya kesamaan latar belakang dan kondisi geografis serta saling membutuhkkan satu sama lain sehingga komunikasi yang dibangun

${ }^{12}$ Sofyan Hadi, Ilmu Dakwah, Dari Konsep Paradigma Hingga Metodologi (Jember : Center for Society Studies, 2012), 67 
antar sesama masyarakat umat beragama di desa Sukoreno tanpa ada hambatan, sehingga kondisi mayarakat saling memahami dan saling mengerti, artinya komunikasi yang dibangun oleh masyarakat muslim Sukoreno berada dalam koridor seperangkat nilai yang dianut masyarakat sehingga keberdaan komunikasi yang sesuai dengan norma-norma yang berlaku di masyarakat Sujoreno tidak banyak dipertentangkan.

2. Pola Komunikasi Masyarakat Muslim dalam menjaga kerukunan masyarakat Multi Agama di desa Sukoreno kecamatan Umbulsari kabupaten Jember

Pola komunikasi dapat diartikan sebagai bentuk hubungan antar dua orang atau kebih dalam proses mengirim dan menerima pesan dengan tepat sehingga transaksi simbol antara kedua oramg atau lebih itu saling mengerti dan memahami maksud dari pesan yang disampaikan. ${ }^{13}$ Masyarakat muslim Sukoreno di dalam menjaga kerukunan umat beragama menggunakan pola komunikasi langsung dengan saling menghargai dan saling mengayomi antar individu masyarakat.

Realitas masyarakat desa Sukoreno sebagai kaum mayoritas masyarakat muslim Sukoreno mengayomi masyarakat minoritas non muslim, sebaliknya masyarakat non muslim yang notabene adalah kelompok mayarakat minoritas menghargai kelompok mayoritas. Realitas ini menunjukkan bahwa pola komunikasi masyarakat Muslim Sukoreno adalah pola komunikasi timbal balik.

Kerukunan yang berarti kedamaian merupakan tujuan dari kehidupan umat beragama, sebab dengan adanya kedamaian tentu hidup akan menjadi rukun dan sebaliknya kerukunan yang terbangun dalam sosial masyarakat akan melahirkan kehidupan yang damai.

Pola komunikasi dalam menjaga kerukunan umat beragama di desa Sukoreno juga dinyatakan oleh beberapa informan ketika masyarakat Sukoreno mengadakan hajatan, ketika diundang mereka saling datang untuk menghadiri kenduri tanpa membedakan agama yang mereka anut. Kemudian masyarakat muslim Sukoreno di dalam mejaga kerukunan umat beragama tidak berkomunikasi yang mengarah pada keyakinan agama yang dianut masyarakat

${ }^{13}$ Syaiful Bahri Djamarah,Pola Komunikasi Orang Tua dan Anak dalam keluarga (Jakarta: PT. Reneka Cipta. 2004), 1 

bilamana komunikan berupa seorang yang berbeda agama. Saling menghargai satu dengan yang lain dan komunikasi yang dibangun tidak saling mendominasi juga merupakan bagian dari pola komunikasi yang diterapkan oleh masyarakat Muslim Sukoreno dalam menjaga kerukunan umat beragama.

Bicara berlebihan dan apalagi berbicara dengan sesuatu yang tidak sesuai dengan realitas sesungguhnya akan menjadikan hubungan yang tidak harmonis sebab di dalam pembicaraan yang terlalu berlebihan cenderung akan melahirkan unsur ketidaksukaan lawan bicara. Bagi masyarakat muslim Sukoreno bicara dengan sederhana dan tidak berlebihan dilakukan untuk menjaga agar hidup tetap dapat bisa akur dan guyub rukun antar sesama umat beragama.

Selain hal di atas, masyarakat muslim Sukoreno dalam menjaga kerukunan umat beragama berusaha selalu sadar diri akan hakikat manusia yang saling membutuhkan satu dengan yang lain tanpa memandang ras, agama dan kepercayaan lainnya, komunikasi yang dilakukan dengan cara tidak mau menangnya sendiri, sehingga interaksi yang dibangun antar individu yang terlibat komunikasi menjadi akur. Dan ke akuran ini yang akan melahirkan kerukunan.

Etika komunikasi Islam masyarakat Muslim di tengah kehidupan masyarakat multi agama di desa Sukoreno adalah saling menghargai. Masyarakat desa Sukoreno dalam hal ibadah tetap sendiri-sendiri dengan memberikan kebebasan kepada non muslim untuk beribadah sesuai dengan keyakinan masing-masing, mata pencaharian masyarakat Sukoreno mayoritas petani dan buruh tani, hal ini menjadikan temapt mereka bekerja adalah sama-sama di sawah. Adakalanya masyarakat Sukoreno berada dalam satu sawah saat bekerja dan itu berbaur antara muslim Sukoreno dengan non muslim. Komunikasi yang saling menghargai antar masyarakat muslim dengan non muslim terlihat pada saat bulan ramadhan mereka bekerja dalam satu tempat, namun pada saat makan di sawah (dikirim pemilih tanah) masyarakat yang tidak beragama Islam tetap makan karena mereka yang non muslim tidak merasa adanaya kewajiban puasa ramadhan, sementara masyarakat yang beragama Islam tetap bersamasama berada di sawah tidak mengganggu orang yang non muslim. Masyarakat muslim duduk istirahat sembari menunggu masyarakat non muslim makan selesai dan kemudian bekerja bersama-sama lagi. 
Komunikasi non verbal berupa gerak tubuh (tidak menganggu) masyarakat non muslim yang sedang makan di sawah pada siang hari ini menunjukkan adanya saling menghargai antar sesama umat beragama di desa Sukoreno. Perikalu lain yang ditunjukkan oleh masyarakat muslim Sukoreno adalah hadirnya masyarakat muslim pada acara hajatan tertentu yang dilakukan oleh non muslim. Masyarakat non muslim di desa Sokoreno kalau mempunyai hajatan tertentu -kalau dalam versi islam selamatenan, kenduri dan semacamnya- turut mengundang orang islam yang bertetangga dengan yang punya hajat tersebut.

Etika komunikasi Islam masyarakat Muslim di tengah kehidupan masyarakat multi agama di desa Sukoreno adalah berbicara apa adanya dan tidak berlebihan. sebagaimana pernyataan Slamet warga Sukoreno dusun Krajan Kidul, ketika berbicara dengan masyarakat yang berbeda agama dia berbicara sederhana, tidak berlebihan dan apa adanya. Berbicara apa adanya merupakan etika komunkasi yang dibangun masyarakat muslim Sukoreno di dalam hubungan sosial dengan masyarakat multi agama. Artinya pembicaraan sederhana, apa adanya dan tidak berlebihan ini merupakan kesesuaian antara pesan-pesan yang ditransmisikan kepada komunikan dengan realitas riil yang terjadi dan dialami oleh komunikator.

Kemudian Etika komunikasi Islam masyarakat Muslim di tengah kehidupan masyarakat multi agama di desa Sukoreno adalah pembicaraan yang tidak menyinggung persoalan keyakinan. Sebagaimana pernytaan Slamet dalam berinteraksi dengan masyarakat multi agama, masyarakat muslim Sukoreno tidak pernah menyinggung tentang keyakinan masyarakat. Karena bagi masyarakat Sukoreno terkait masalah keyakinan itu sendiri-sendiri, sama-sama punya hak untuk meyakini agama untuk dianutnya. Selain hal di atas etika komunikasi Islam masyarakat Muslim di tengah kehidupanmasyarakat multi agama adalah dengan perkataan yang lemah dan lembut serta tidak memaksakan kehendak.

Adapun pola komunikasi masyarakat muslim Sukoreno dalam menjaga kerukunan umat beragama adalah pola komunikasi dua arah dan linier. Komunikasi antara individu di masyarakat Suoreno bellangsung dua arah artinya sikulus pesan yang berada pada dua individu atau lebih yang terlibat dalam 

proses komunikasi adalah efektif. Mereka saling memahami makna di balik media (bahasa) yang digunkan dalam berbicara sehari-hari.

\section{KESIMPULAN DAN SARAN}

Etika Komunikasi Islam Masyarakat Muslim yang diterapkan dalam masyarakat Multi Agama di desa Sukoreno kecamatan Umbulsari kabupaten Jember

Etika komunkiasi Islam yang diterapkan masyarakat muslim di dalam kehidupan masyarakat multi agama adalah komunikasi non verbal berupa tindakan atau perilaku masyarakat muslim Sukoreno dengan menghadiri hajatan orang non mulim, kedua etika komunikasi yang dibangaun masyarakat muslim Sukoreno adalah dengan berucap atau berkata-kata yang sederhana, apa adanya dan tidak berlebihqn. ketiga, komunkais yang dibangun adalah komunikasi yang tidak menyinggung persoalan keyakinan dalam beragama. Keempat, etika komunikasi yang dibangun masyarakat muslim Sukoreno adalah dengan menggukan kata-kata yang lemah lembut, tidak memaksa. Etika komunikasi masyarakat muslim Sokoreno juga dterapkan dengan memposisikan agama sebagai nilai atau institusi sosial yang mengatur jalianan hidup antar sesama manusia.

Pola Komunikasi Masyarakat Muslim dalam menjaga kerukunan masyarakat Multi Agama di desa Sukoreno kecamatan Umbulsari kabupaten Jember

Pola komunikasi yang diterapkan masyarakat muslim Sukoreno di dalam menjaga kerukunan umat beragama adalah dengan cara berhati-hati di dalam pembicraan dan tidak menunjukkan sikap sombong. Pesan yang diampsikan di dalam komunikasi masyaraat muslim Sukoreno tidak mengandung unsur intimidasi, dan pada saat duduk bersama dalam acara tertentu tidak memdeda-bedakan latar agama yang dianut. Selain itu, masyarakat Sukoreno di dalam menjaga kerukunan umat beragama tidak menyinggung keyakinan dalam berkomunikasi.

\section{SARAN}

Berdasarkan hasil penelitian yang telah dipaparkan di atas, peneliti memiliki saran di ataranya adalah :

1. Masyarakat desa Sukorena terutama tohoh agama yang menjadi pemangku agama harus bisa mempertahankan kerukunan antar umat beragama dengan cara mengkader dan memberikan pemahaman kepada generasi penserusnya. 
2. Masyarakat memang tampak kebersamaannya, namun ada hal yang dikhawatirkan yaitu ketika berkaitan dengan persoalan aqidah yang sewaktuwaktu bisa menimbukan konflik, oleh karenanya perlu adanya kesadaran dalam memupuk keyakinan yang berkaitan dengan hal aqidah di dalam perilaku keberagamaan.

3. Peran pendidikan di desa Sukoreno merupakan peran yang signifikan karenanya pendidikan harus mampu menjadi pelopor di dalam memberikan pemahaman kepada generasi penerus demi tercapainya dan terjaganua kerukunan umat bergama.

4. Kepada tokoh masyarakat, khusunya non muslim, jangan mudah membuat dalil haram yang sekiranya akan menjadi polemik di masyarakat.

\section{DAFTAR PUSTAKA}

BPS Kabupaten Jember,. 2018. Kecamatan Umbulsari dengan angka 2018. Jember : BPS Jember

BPS Kabupaten Jember, 2019.Kecamatan Umbulsari Dalam Anga 2018. Jember : BPS Jember

Djamarah, Syaiful Bahri. Pola Komunikasi Orang Tua dan Anak dalam keluarga (Jakarta: PT. Reneka Cipta. 2004)

Hadi, Sofyan. Ilmu Dakwah, Dari Konsep Paradigma Hingga Metodologi (Jember : Center for Society Studies, 2012)

Kriyantono, Rahmat. Teknik Riset Komunikasi (Jakarta : Kencana, 2008)

Raharjo, Mudjia. Studi kasus dalam penelitian kualitatif (Bandung : Remaja Rosda Karya, 2017)

Hasil Wawancara:

Samsul Huda, wawancara Sukoreno (28 Januari 2020)

Nurhayati, Sukoreno, wawancara (21 Januari 2020)

Website:

Kompas .com

Tribun medan.com

www.uscrirf.Gov 
Etika Komunikasi Islam Masyarakat Muslim Yang Diterapkan Dalam Masyarakat Multi-Agama Di Desa Sukoreno Kecamatan Umbulsari Kabupaten Jember 